\title{
Iron deficiency anemia with thrombocytosis on a health checkup
}

\author{
Sayaka KaWAno $^{1}$ Johji Kato $^{2}$ Kazuo Kitamura $^{1}$ \\ ${ }^{I}$ Department of Internal Medicine, Circulatory and Body Fluid Regulation, Faculty of Medicine, University of Miyazaki \\ ${ }^{2}$ Frontier Science Research Center, University of Miyazaki
}

\begin{abstract}
Iron deficiency anemia is reported to have malignant and non-malignant etiologies, including gastro-intestinal bleeding and uterine leiomyoma. Iron deficiency anemia has been associated with secondary thrombocytosis. Furthermore, iron deficiency anemia with thrombocytosis may lead to the development of fatal thrombotic disorders.

Here, we report the case of a 45-year-old asymptomatic woman with severe anemia $(\mathrm{Hb} 5.9 \mathrm{~g} / \mathrm{dL})$ and thrombocytosis $\left(461.0 \times 10^{9} / \mathrm{L}\right)$ that was detected during a blood test performed as part of a routine health checkup. Based on the findings from the blood test, the patient was clinically diagnosed with iron deficiency anemia with thrombocytosis. Thereafter, computed tomography (CT) revealed uterine leiomyoma which causes chronic anemia. The iron deficiency anemia with thrombocytosis improved following treatment with an oral iron supplement. Furthermore, we discussed the literature review about iron deficiency anemia with thrombocytosis resulting in thrombotic disorders.

(HEP. 2020; 47: 516-518.)
\end{abstract}

Key words iron deficiency anemia, thrombocytosis, thrombotic disorders, health checkup

\section{Introduction}

Iron deficiency anemia is reported to have various etiologies including malignancies such as gastric and colon cancer, as well as non-malignant etiologies including gastric and duodenal ulcer and gynecological disorders such as menstrual blood loss with uterine leiomyoma. Of these etiologies, it is essential to rule out asymptomatic cases of malignancy during the early stages based on anemia findings from blood tests performed during health checkups.

Here, we report the case of a woman who presented with severe anemia and thrombocytosis. Furthermore, we discussed the literature review about iron deficiency anemia with thrombocytosis resulting in thrombotic disorders.

\section{Case report}

A 45-year-old asymptomatic woman who was a non-smoker underwent an annual health checkup. The medical history of the examinee was documented by nurses using a questionnaire, which was confirmed by a physician. The questionnaire consisted of the chief complaint, medical history, smoking status, medication use, and family history of disease. The examinee had no symptom such as dizziness or any significant medical or family history of disease. The examinee had a body mass index of 25.1 $\mathrm{kg} / \mathrm{m}^{2}$. Physical examination revealed anemic palpebral conjunctiva. Furthermore, the respiratory sound was clear and heart sound had systolic murmur. Liver and spleen were not palpable.

Received: December 17, 2019, Accepted: April 24, 2020

J-STAGE Advance published: June 9, 2020

Corresponding author: Sayaka Kawano

${ }^{1}$ Address; University of Miyazaki

5200 Kihara, Kiyotake, Miyazaki 889-1692, Japan

TEL: +81-985-85-1510

E-mail: sayakawano23@yahoo.co.jp
The laboratory findings on health checkup are shown in Table $\mathbf{1 .}$ The urinary examination findings were normal. The feces occult blood test was negative. The laboratory finding revealed a decrease of $\mathrm{Hb}(5.9 \mathrm{~g} / \mathrm{dL})$, Hct (23.0\%), MCV (57.6 fL), MCH $(14.8 \mathrm{pg})$, and $\mathrm{MCHC}(25.7 \mathrm{~g} / \mathrm{dL})$ and an increase of platelet count $\left(461.0 \times 10^{9} / \mathrm{L}\right)$. Previous medical records were reviewed to determine the change in anemia, and it was found that the anemia had got worse (Table 2). The electrocardiogram showed normal sinus rhythm and flat $\mathrm{T}$ wave in lead III, aVF. Chest X-ray revealed cardiomegaly (CTR 58\%). Double-contrast upper gastrointestinal barium X-ray radiography was normal.

Accordingly, a referral to the department of Internal Medicine at our institution was made on the same day after health checkup. Further examination revealed that serum iron was $8 \mu \mathrm{g} / \mathrm{dL}$, total iron binding capacity was $481 \mu \mathrm{g} / \mathrm{dL}$, whereas ferritin was less than $3 \mathrm{ng} / \mathrm{mL}$. Abdominal CT revealed uterine leiomyoma $(4 \mathrm{~cm})$, which causes chronic anemia.

Consequently, a final diagnosis of iron deficiency anemia with thrombocytosis was made. According to the guidelines for the

Table 1 Laboratory findings on health checkup

\begin{tabular}{lclc}
\hline & $2019 / 10 / 08$ & $2019 / 10 / 08$ \\
\hline WBC $\left(\times 10^{9} / \mathrm{L}\right)$ & 6.6 & AST $(\mathrm{U} / \mathrm{L})$ & 17 \\
RBC $\left(\times 10^{6} / \mu \mathrm{L}\right)$ & 3.99 & ALT $(\mathrm{U} / \mathrm{L})$ & 10 \\
$\mathrm{Hb}(\mathrm{g} / \mathrm{dL})$ & 5.9 & $\gamma$-GTP $(\mathrm{U} / \mathrm{L})$ & 9 \\
$\mathrm{Hct}(\%)$ & 23.0 & ALP $(\mathrm{U} / \mathrm{L})$ & 138 \\
$\mathrm{MCV}(\mathrm{fL})$ & 57.6 & Cre $(\mathrm{mg} / \mathrm{dL})$ & 0.48 \\
$\mathrm{MCH}(\mathrm{pg})$ & 14.8 & UA $(\mathrm{mg} / \mathrm{dL})$ & 3.3 \\
$\mathrm{MCHC}(\mathrm{g} / \mathrm{dL})$ & 25.7 & T-cho $(\mathrm{mg} / \mathrm{dL})$ & 139 \\
$\mathrm{Plt}\left(\times 10^{9} / \mathrm{L}\right)$ & 461.0 & TG $(\mathrm{mg} / \mathrm{dL})$ & 46 \\
& & HDL-C $(\mathrm{mg} / \mathrm{dL})$ & 57 \\
& & LDL-C $(\mathrm{mg} / \mathrm{dL})$ & 73 \\
& & FBS $(\mathrm{mg} / \mathrm{dL})$ & 85 \\
\hline
\end{tabular}


Table 2 The changes in laboratory findings detected on health checkup

\begin{tabular}{lccccc}
\hline & 2016 & 2017 & 2018 & 2019 & 2019 \\
& $10 / 27$ & $10 / 24$ & $11 / 15$ & $10 / 8$ & $11 / 14$ \\
\hline \multicolumn{5}{c}{$\begin{array}{c}\text { Medical health checkup } \\
\text { (pre therapy) }\end{array}$} & $\begin{array}{c}\text { Internal Medicine } \\
\text { (post therapy) }\end{array}$ \\
\hline WBC $\left(\times 10^{9} / \mathrm{L}\right)$ & 4.43 & 7.36 & 5.43 & 6.6 & 5.5 \\
$\mathrm{RBC}\left(\times 10^{6} / \mu \mathrm{L}\right)$ & 3.97 & 4.39 & 4.14 & 3.99 & 4.45 \\
$\mathrm{Hb}(\mathrm{g} / \mathrm{dL})$ & 7.9 & 7.3 & 6.4 & 5.9 & 8.4 \\
$\mathrm{Hct}(\%)$ & 26.5 & 27.1 & 24.4 & 23.0 & 31.2 \\
$\mathrm{MCV}(\mathrm{fL})$ & n.e. & n.e. & n.e. & 57.6 & 70.1 \\
$\mathrm{MCH}(\mathrm{pg})$ & n.e. & n.e. & n.e. & 14.8 & 18.9 \\
$\mathrm{MCHC}(\mathrm{g} / \mathrm{dL})$ & n.e. & n.e. & n.e. & 25.7 & 26.9 \\
$\mathrm{Plt}\left(\times 10^{9} / \mathrm{L}\right)$ & n.e. & n.e. & n.e. & 461.0 & 417.0 \\
\hline & & & & &
\end{tabular}

Table 3 Adult cases of thrombosis associated with iron deficiency anemia with thrombosis

\begin{tabular}{|c|c|c|c|c|c|c|}
\hline Case & & Age & Gender & $\begin{array}{l}\text { Platelet } \\
\left(\times 10^{9} / \mathrm{L}\right)\end{array}$ & $\begin{array}{l}\text { The sites of thrombosis/ } \\
\text { Thrombotic complications }\end{array}$ & $\begin{array}{c}\text { Complication } \\
\text { (HT,DM,dyslipidemia, } \\
\text { drinking, smoking, } \\
\text { and others) }\end{array}$ \\
\hline Case 1 & Nagai et al (ref 5) & 29 & female & 1,020 & $\begin{array}{l}\text { Multiple pulmonary } \\
\text { thromboembolism }\end{array}$ & Not described \\
\hline Case 2 & Keung et al (ref 7) & 32 & female & 865 & $\begin{array}{l}\text { Extensive infarct of the } \\
\text { right middle cerebral } \\
\text { artery territory }\end{array}$ & None \\
\hline Case 3 & Keung et al (ref 7) & 48 & female & 1,139 & Transient hemiparesis & None \\
\hline Case 4 & $\begin{array}{l}\text { Keung et al's review } \\
\text { (ref 7) }\end{array}$ & 42 & male & 1,016 & Transient hemiparesis & Hemorrhoid \\
\hline Case 5 & $\begin{array}{l}\text { Keung et al's review } \\
\text { (ref } 7 \text { ) }\end{array}$ & 42 & female & 1,736 & hemiparesis & Uterine fibroid \\
\hline Case 6 & $\begin{array}{l}\text { Keung et al's review } \\
\text { (ref } 7 \text { ) }\end{array}$ & 26 & female & 850 & $\begin{array}{l}\text { Thrombosis of middle } \\
\text { cerebral artery region }\end{array}$ & Uterine fibroid \\
\hline Case 7 & $\begin{array}{l}\text { Keung et al's review } \\
\text { (ref 7) }\end{array}$ & 30 & female & 1,050 & Right parietooccipital infarct & Uterine fibroid \\
\hline Case 8 & $\begin{array}{l}\text { Keung et al's review } \\
\text { (ref 7) }\end{array}$ & 44 & female & 666 & $\begin{array}{l}\text { Thrombosis in the bulb } \\
\text { of the right } \\
\text { internal carotid artery }\end{array}$ & Menorrhagia \\
\hline Case 9 & $\begin{array}{l}\text { Keung et al's review } \\
\text { (ref } 7 \text { ) }\end{array}$ & 20 & female & 544 & Right parietal infarct & Menorrhagia \\
\hline Case 10 & $\begin{array}{l}\text { Keung et al's review } \\
\text { (ref } 7 \text { ) }\end{array}$ & 39 & female & 652 & $\begin{array}{l}\text { Thrombosis in the left } \\
\text { common carotid artery }\end{array}$ & Uterine fibroid \\
\hline Case 11 & $\begin{array}{l}\text { Keung et al's review } \\
\text { (ref 7) }\end{array}$ & 50 & female & 390 & Left eye & Hypermenorrhea \\
\hline Total & & $\begin{array}{l}\text { Median } 39 \\
(20-50)\end{array}$ & $\begin{array}{l}\text { Female } 10 / \\
\text { Male } 1\end{array}$ & $\begin{array}{l}\text { Median } 865 \\
(390-1,736)\end{array}$ & & \\
\hline
\end{tabular}

treatment of anemia ${ }^{1)}$, oral iron supplement was administered immediately.

The patient recovered from anemia and thrombocytosis without development of thrombotic disorders.

\section{Discussion}

We described an asymptomatic case presenting with anemia and thrombocytosis on a health checkup that was finally diagnosed as iron deficiency anemia with thrombocytosis after detailed examination.

Iron deficiency anemia has occasionally been complicated by reactive thrombocytosis in clinical practice. Previous reports regarding iron deficiency anemia with thrombocytosis resulting in thrombotic disorders were summarized in Table 3. Dan reviewed the clinical issues of thrombocytosis in iron deficiency anemia in terms of the degree of thrombocytosis (mild-moderate) and the incidence (7\%) among 100 consecutive patients with iron deficiency anemia. The cases with severe iron deficiency anemia and marked thrombocytosis were complicated with central retinal vein occlusion ${ }^{2-6)}$. Furthermore, Keung et al. reported two cases of iron deficiency anemia and thrombocytosis, which were peripheral, pulmonary and cerebrovascular thrombosis ${ }^{7}$. Further- 
more, Keung et al. summarized the data among the adult cases of thrombosis associated with iron deficiency anemia and thrombocytosis (median $865 \times 10^{9} / \mathrm{L}$, range: $390-1,736 \times 10^{9} / \mathrm{L}$ ) . In Table 3, 1 male and 10 females were reported with female predominance, showing that females were reported to be at a higher risk of thrombosis ${ }^{7}$. Regarding as the age distribution, three cases, four cases, one case were reported in twenties, forties and fifties, respectively ${ }^{7}$. Thus, 11 cases were found in all generations (median 39, range: $20-50)^{7}$. Regarding as platelet counts, one case (case 11), one case (case 9), two cases (case 8 and 10), three cases (case 1,4 , and 7 ) were $390 \times 10^{9} / \mu \mathrm{L}, 540 \times 10^{9} / \mu \mathrm{L}, 600 \times$ $10^{9} / \mu \mathrm{L}$, over $1,000 \times 10^{9} / \mu \mathrm{L}$, respectively ${ }^{7}$. Thus, the thrombosis cases tended to increase in concordance with the increases of the platelet counts ${ }^{7}$. Furthermore, all cases had not described about complications such as atrial fibrillation, hypertension, dyslipidemia and diabetes mellitus ${ }^{7}$.

In our case, the examinee did not consult a doctor for at least four years according to the previous medical records because she indicated that she had no symptoms. Since iron deficiency anemia may occasionally be complicated by reactive thrombocytosis resulting in fatal thrombotic disorders, it is essential to educate patients with anemia and thrombocytosis to consult a doctor. Moreover, although iron deficiency anemia is a common clinical condition, we should recognize the potential complication of reactive thrombocytosis that may result in fatal thrombotic disorders. Thus, we should consult and refer patients to a specialist to perform additional assessments to identify the underlying cause and implement appropriate treatment.

\section{Compliance and ethics standards}

Ethics statement: This case study was conducted in compliance with good clinical practices and the ethics principles of the Declaration of Helsinki.

Informed consent: Informed consent was obtained from the patient for reporting the case details.

The authors state that they have no Conflict of Interest (COI).

\section{REFERENCES}

1) Goddard AF, James MW, McIntyre AS, Scott BB. British Society of Gastroenterology. Guidelines for the management of iron deficiency anaemia 2011; 60(10): 1309-16.

2) Dan K. Thrombosis in Iron Deficiency Anemia, Internal Med 2005; 44(10): 1025-6.

3) Schloesser LL, Kipp MA, Wenzel FJ. Thrombocytosis in irondeficiency anemia. J Lab\&Clin Med 1965; 66: 107-14.

4) Kasper CK, Whissell DY, Wallerstein RO. Clinical aspects of iron deficiency. JAMA 1965; 191: 359-63.

5) Nagai T, Komatsu N, Sakata Y, Miura Y, Ozawa K. Iron deficiency anemia with marked thrombocytosis complicated by central retinal vein occlusion. Internal Med 2005; 44: 1090-2.

6) Akins PT, Glenn S, Nemeth PM, Derdeyn CP. Carotid artery thrombus associated with severe iron-deficiency anemia and thrombocytosis. Stroke 1996; 27: 1002-5.

7) Keung YK, Owen J. Iron deficiency and thrombosis: literature review. Clin Appl Thromb Hemost 2004; 10(4): 387-91. 